\title{
English Language Attrition Amidst Covid-19 Pandemic. What Happens When Schools Close?
}

\author{
Sara Zinyuk ${ }^{*}$, Josiah Mwachi Waiti ${ }^{\text {** }}$ \\ * Doctorate student, Department of Educational Administration and Planning, School of Education, University of Nairobi, Kenya \\ ** Doctorate student, Department of Educational Administration and Planning, School of Education, University of Nairobi, Kenya \\ DOI: 10.29322/IJSRP.11.08.2021.p11615 \\ http://dx.doi.org/10.29322/IJSRP.11.08.2021.p11615
}

\begin{abstract}
This study sought to establish aspects of written English grammar that incurred attrition due to the long closure of schools amidst Covid-19 pandemic. Kenyan secondary school students learn listening and speaking, reading and writing skills through English, the language of instruction (LOI), a second language which attrited dismally amidst the Covid-19 pandemic making educators, teachers of English and the general Kenyan public worried. Language attrition in Kenyan secondary schools was three-fold. First, as a result of declining use of English as a second language by students who changed their linguistic environment, that is students' discontinued contact with the L2 in classroom practices. Second, this happened when students' contact with the L2 was limited or interrupted, changing language habits as it was frequently done in the classrooms. The third scenario is where students faced a great competition with other linguistic systems, being immersed in L1 dominant settings in their communities. Various factors influencing English language attrition have been expounded in this paper to include: the time of attrition, the L2 proficiency level before and during attrition. The study used descriptive research design and purposive sampling for data collection. 106 students wrote a 40-minute guided composition within the first week upon school resumption. 32 students whose proficiency in English was excellent before the long nine months school closure were specifically selected for the study. Data was presented using tables and frequencies tabulated. The study concluded that reduced and or diminished opportunities for L2 (English) do cause considerable attrition in grammar and that different aspects of grammar attrite differently during this period.
\end{abstract}

Index Terms- Attrition, Second Language, Covid-19 Pandemic, Proficiency, Writing skills, Grammar skills.

\section{INTRODUCTION}

$\mathrm{K}$ upske (2020) shows that language attrition is basically threefold where there is $L_{1}$ loss in $L_{2}$ setting. This happens when the contact with the $L_{1}$ is limited or interrupted or when there is a great competition with other linguistic systems, as in the case of first-generation immigrants immersed in and $\mathrm{L}_{2}$ dominant setting. Another scenario is when there is $\mathrm{L}_{1}$ loss in $\mathrm{L}_{1}$ dominant environment as can be experienced when highly proficient bilinguals are frequently in contact with an $\mathrm{L}_{2}$ setting such as teachers of languages. The third scenario is where there is $\mathrm{L}_{2}$ loss in $\mathrm{L}_{1}$ setting where learners of an additional language or $\mathrm{L}_{1}$ migrant returnees discontinue contact with the $\mathrm{L}_{2}$.
Park (2018) sees language attrition as the partial or complete loss of any language $\left(\mathrm{L}_{1}, \mathrm{~L}_{2} \ldots\right.$ etc.)

According to Schmid (2011), 'Language attrition describes the loss of, or changes to, grammatical and other features of a language as a result of declining use by speakers who have changed their linguistic environment and language habits.'

The process of language attrition notes Tang (2011) 'is closely related to that of language shift and that it is predicted that if individuals lose their ability to use $\mathrm{L}_{2}$ in their community, they will feel reluctant to use it and will shift towards the dominant language of the catchment area as a means of expression and communication. Then as the language shift continues, their opportunities to use $\mathrm{L}_{2}$ become reduced, causing further erosion of $\mathrm{L}_{2}$ proficiency.' This can be attributed to the fact that language (s) do not create vacuums. In a multilingual environment, the dominant language and the language of the catchment area will be spoken more than other languages. This is explained further by O'Grady et al (2009) that when a language is less accessible through infrequent use, its speakers become more reluctant to use it, which decreases its accessibility and creates the cycle that ultimately leads to partial acquisition, attrition or loss.

Olshtain (1989) affirms that attrition can be as a result of change in linguistic environment or to the termination of an instructional program. Cleroux (2013) contends that 'unfortunately, after all the work and effort put into learning a second language, too much is lost when the active commitment to learning ends. When it comes to $\mathrm{L}_{2}$, if the learners are not making use of their newly acquired skills, these skills appear to rapidly vanish.' This is further asserted by Gardner et al (1985) who shows that 'those who try to maintain their second language skills are relatively successful, whereas those who do not do so experience considerable language loss'. Myers-Scotton (2006) says that attrition implies the first steps towards loss of a language and replacement by another.

Schmid and Mehotcheva, (2012) presuppose that $\mathrm{L}_{2}$ will be forgotten when it is not used or studied despite where and how it was developed. Meara (2004) argues that the process of attrition may not lead to vocabulary loss, direct changes, but would weaken linguistic structures. 


\section{BACKGROUND TO THE RESEARCH}

Kenya is a multicultural, multilingual country. Lewis et al (2015) quoted by Piper et al (2016) confirm that there are sixtyseven living languages spoken in Kenya. The language of instruction (LOI) in Kenyan schools is English which is also the official language in the country. It is taught as a second language (ESL). Kiswahili is the lingua-franca of the country, and it is also taught as a subject in schools. Learners also acquire their vernacular language and /or other languages of their catchment area before and as they commence formal learning. As such most learners are multilingual speaking their vernacular languages, English $\left(\mathrm{L}_{2}\right)$ and Kiswahili. Kaviti (2018) notes that 'children possess the ability to competently acquire their mother tongue and simultaneously acquire other languages, including a national lingua franca (for regional and national communication) and a language such as English (for global communication).

\section{LITERATURE REVIEW}

Language attrition asserts Hansen, (2001a) in Marefat and Rouhshad (2007), 'is studied for two reasons: first, researchers have taken interest in knowing attrition process and second, it has considerable pedagogical implications.' Tang (2011) quoting Yagmur (1997) further notes that the understanding of attrition 'varies depending on the focus of research. That focus can be what is lost (linguistic aspects), why it is lost (sociological aspects), or how it is lost (psychological aspects). Tang (2011) reiterates that 'many researchers agree that language attrition is determined by both linguistic and extralinguistic factors (e.g., external and social) factors. It is crucial to note that 'when a language is less accessible through infrequent use, its speakers become more reluctant to use it, which decreases its accessibility and creates the cycle that ultimately leads to partial acquisition, attrition, or loss. When it comes to learning and acquiring a second language $\left(\mathrm{L}_{2}\right)$, Schmid and Bardovi-Harling and Stringer (2010) in their literature review of second language attrition note that 'studies of attrition in learners of second or foreign languages are found in literature at least as early as 1929 and that the first studies investigated the question of loss of foreign language skills by high school and college students during summer vacations (Cole, 1929, for French; Kennedy, 1932, for Latin; Scherer, 1957, for German). There were two further studies on French by Smythe, Juntras, Bramwell, and Gardner (1973).'

Pyrzanowska (2016) discuss that 'research on $\mathrm{L}_{2}$ attrition dates back to 1980 in the University of Pennsylvania as a subfield to SLA (second language acquisition) in a conference on the loss of language skills and subsequent papers published by Lambert and Freed in 1982 in 'The loss of language skills', where criterion and predictor variables were distinguished.' These linguistic variables subsume factors such as: lexical, morphosyntactic influence from the dominant language, frequency of input, loss of morphological complexity, a reduction in registers of use; whereas extralinguistic variables subsume factors such as; the age of the learners, length of time without input and motivation for language maintenance.

This publication is licensed under Creative Commons Attribution CC BY

http://dx.doi.org/10.29322/IJSRP.11.08.2021.p11615
Noteworthy is that many studies of language attrition have concentrated their efforts on the language skills as opposed to linguistic elements. This is elaborated by Bahrick (1984) that 'much effort is devoted to the acquisition of foreign language skills, but little is known about their rate of attrition. Knowledge about attrition would yield benefits to teachers and students of foreign languages, because it would lead to understanding how various procedures of acquisition affect the rate of loss and would ultimately help to establish optimum conditions of rehearsal so as to minimise the potential of later attrition and that language scholars have shown awareness of the need for accurate information to this subject.'

Bahrick (2011) confounds that 'language scholars have until recently shown little inclinations to explore the problems of language attrition systematically, probably because they have considered it a pedagogical problem of tangential concern.'

\section{FACTORS AFFECTING LANGUAGE ATTRITION}

There are various factors that trigger language attrition. Feng (2016) confirms that firstly the time of attrition plays a very crucial role in language attrition. This is because in traditional sense, time is considered to be the primary influencing factor in the occurrence of language attrition. The study of language attrition involves the time span of three months, one year to four years, twenty-five years to thirty-five years and fifty years.' No contact or reduced contact to a language for a considerable amount of time is one of the most primary factors causing language attrition.

Secondly, the foreign language level before attrition and its proficiency level of the learner prior to attrition plays an important role in determining the level of attrition. Thirdly, the linguistic environment contact with attrition language determines attrition. If there are competing languages, the linguistic dominant language in the social environment of the learner will compete with the second language. Pyrzanowska (2016) says that 'prolonged disuse of a particular language co-occurring with an intense exposure to a different language triggers an increase in the activation level' of the linguistic language of the catchment area.

Fourthly, research points out that children's foreign language level is more easily attrited than that of adults. Olshtain (1986) shows that this is because older children retain more than younger children because they have $\mathrm{L}_{2}$ literacy skills.

Fifthly, Bahrick (1984) found out that productive skills attrite more than receptive skills. Productive skills namely speaking, and writing are more vulnerable to attrition than receptive skills namely listening and reading (Bahrick, 1984a, 1984b; Hedgcock, 1991; Lowe, 1982; Scherer, 1957; Snow et al., 1988; Tomiyama, 1999a, 1999b). Receptive vocabulary (as opposed to vocabulary that is produced) and receptive grammar are also included as receptive skills although neither is a skill but rather a component of the $\mathrm{L}_{2}$ grammar and that vocabulary also figures in an undefined skill called understanding, Scherer (1957).

Subsequently, social emotional factors which influence the external motivation that a learner has to engage in $\mathrm{L}_{2}$ in a linguistic environment dominated by another language (s). Another factor is 
reading and writing abilities which help in the maintenance of $\mathrm{L}_{2}$. Learners who are inclined to read and write in $\mathrm{L}_{2}$ minimise the rate of attrition of $\mathrm{L}_{2}$. Gardner et al (1985) as quoted by Cleroux (2013) note that 'those who try to maintain their second language skills are relatively successful, whereas those who do not do so experience considerable language loss.' Noteworthy is the issue of loss versus accessibility which is elaborated by Kopke and Schmid (2004) who note that attrition at the level of competence involves underlying linguistic competence and includes a restructuring of what is known about the language. Attrition at the level of performance results in control of that knowledge which may remain intact. Kopke and Schmid (2004) propose two types of manifestations of performance attrition: word finding difficulties and processing difficulties. For word finding difficulties, Ammerlaan's (1996) and Hulsen's (2000) psycholinguistic studies show differentials between productive and receptive language skills on the lexical level.

\section{HOW TO REDUCE ATTRITION}

Ayang (2011) professes that language maintenance especially in $\mathrm{L}_{2}$ requires literacy and use, 'language is deeply related with activation and inhibition and has been proposed as an important factor in language attrition'. Tang (2011) quoting Bot (2004) shows that 'the average multilingual is faced with the fact that all those languages in the system need maintenance and advance use to keep them.'

Ouane and Glanz (2011) contend that since reading and writing are cognitively highly challenging tasks, it is often underestimated how important it is to practice reading and writing skills out of school and that it is primarily these practices which motivate learners to become literate. Further, learning a second language requires social communication and academic language.

Schmid (2002) further notes that language maintenance requires social contacts which are dependent on individual choices multilinguals make in deciding which language to use in what context and social opportunities that present $\mathrm{L}_{2}$ use.

\section{Other Scholars related works and findings:}

Gardner et al (1987) conducted a research to establish the role of motivation and use in second language attrition on ninety-eight 12 grade French students in five different London and Ontario schools who were tested in two occasions. The last week of school in June before summer holidays and the first week of school in September. They were assessed for various tasks including productivity, grammatical inaccuracy, vocabulary use, style and syntax, listening comprehension, speaking, reading, writing, attitudes, motivation, understanding and use. The findings revealed that the extent to which language is retained is dependent to some extent upon the learners use an $\mathrm{L}_{2}$ after training has ceased. The findings further show that factors such as attitudes and motivational use of the learner play a significant role in language maintenance. Furthermore, the linguistic environment must be available for learners to have opportunities to use their $\mathrm{L}_{2}$.

Marefat and Rouhshad (2007) investigated $\mathrm{L}_{2}$ attrition of vocabulary in adult Iranian learners of English at four different proficiency levels. The findings show that there was reduced performance in concrete nouns after 3 months of non-exposure and that non-contextualised nouns suffered attrition resulting in reduced proficiency. Low frequency words also suffered attrition. The investigation concluded that attrition takes place at different proportions for both continuing and non-continuing learners and that non-continuing learners suffered more attrition in productive vocabulary. This research has pedagogical implications indicating that contextualisation of vocabulary should be emphasized to resist $\mathrm{L}_{2}$ attrition.

From the literature review above, it is evident that language attrition does take place in languages. Further, that language attrition studies and research have concentrated on bilingual studies. Multilingual studies have not received as much investment.

\section{STATEMENT OF THE PROBLEM}

Learning institutions in Kenya were closed by Friday March $20^{\text {th }}, 2020$ due to the Covid-19 pandemic as the government geared to control transmissions. This immediate closure together with the health measures put in place to keep citizens safe and healthy such as curfews, lockdowns, facemask wearing, stay at home directives and social distancing measures kept many learners without other forms of learning especially so if their schools' and parents did not embrace digital learning forums. Ayang (2011) asserts that language maintenance especially so in $\mathrm{L}_{2}$ requires literacy and use. This is echoed by Schmid (2002) who show that language maintenance requires social contacts and opportunities for use. Kenya being a multilingual society and many learners coming from varied linguistic backgrounds, the language of the catchment area undoubtedly plays dominance in language choice and use.

Kenya initiated phased reopening of all schools with examinable cohorts resuming in-person learning on $12^{\text {th }}$ October 2020 and all schools reopening on $4^{\text {th }}$ January 2021 for all learners. Upon resumption, it was evident that after close to nine and a half months closure of all learning institutions learners were struggling with various aspects of learning including proficiency in the English language which is the medium of instruction.

Research shows that learners of a second language will suffer attrition if the use of the $L_{2}$ is reduced or diminished. During eventualities and a pandemic, the opportunities to continue learning and maintaining language formally are reduced or diminished. This research seeks to find out what language attrition took place in form four students at Masinde Muliro Memorial Secondary School after a prolonged closure of schools and is guided by the following question:

What aspects of grammar incurred attrition amid Covid-19 pandemic due to the long closure of schools?

\section{Research objective}

The objective of the research is to find out which aspects of grammar suffered attrition amid Covid-19 pandemic due to the long closure of schools. 


\section{Theory that supports the research}

The activation and inhibition theory further developed by Paradis (2004) as Activation Threshold Hypothesis is used. Ayang (2011) quoting Penfield and Roberts (1959) and Paradis (2004) explains that this theory is basically a theory purporting frequency of use as the biggest determiner in language retention and maintenance. Quoting Bot (2004) Ayang (2011) affirms that a language that is not used will attrite because it is pushed to the background which makes it accordingly more difficult to access and that the average multilingual is faced with the fact that all those languages in the system need maintenance and advance use to keep them. Activation Threshold
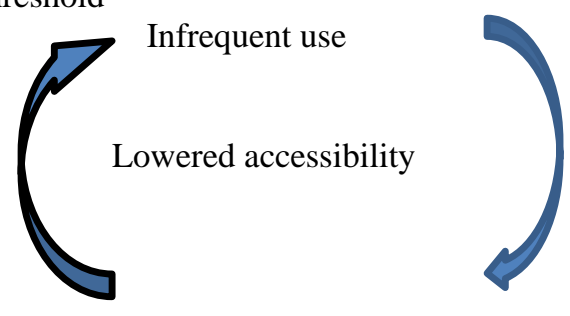

This it is agreed shows that only frequency of use can maintain accessibility of a language and frequency of language use is closely correlated with the level of activation and speed of access, Ayang (2011) quoting O'Grady et al (2009), Alario, Costa, and Caramzza 2002; Bates et al 2003; Jeschniak and Levelt 1994).
Hypothesis says Ayang (2011) assumes that a certain amount of neural impulses is needed in order to reach activation whose most important factor us use. In a nutshell, items that are more frequently used in the $\mathrm{L}_{2}$ will be more easily activated when they are competing with less frequently used items in the $\mathrm{L}_{1}$. This theory concludes that if items are not stimulated, they become more and more difficult to activate over time. Therefore, attrition is the result of a long-term lack of stimulation. Intensive use / exposure to one of the languages in a bilingual (multilingual) environment leads to a lower activation threshold for that language. This is exemplified by Ayang (2011) diagrammatically as follows:

\section{Independent \\ Independent
Variable}

Out of school factors

Covid-19 health protocols

- Social distancing

- $\quad$ Stay at home directives

- Lockdowns

- Mask wearing

Lack of / minimum remote teaching and learning platforms

Lack of smartphones

Lack of/ poor internet connectivity

Expensive internet bundles Unreliable power supply

\section{Conceptual framework}

Maithya et al (2013) says that a conceptual framework is a 'representation of a researcher's conceptualization of the relationship between variables in the research which is shown diagrammatically.' It is the description of concepts in a research and the mapping of the relationships among variables.
Intervening Variable

\section{Dependent variable}

Covid-19 pandemic

$9_{1 / 2}$ months schools' closure
Proficiency in $\mathrm{L}_{2}$ English

Academic achievements

\section{Figure 2.1: Conceptual Framework to the Study}

\section{METHODOLOGY}

\subsection{The sampling procedure}

Form four students were conveniently chosen in this study because this is the examinable cohort that resumed school on $12^{\text {th }}$ October 2020 after nine-and-a-half-months closure due to Covid19 pandemic. The study targeted 106 students. Each student wrote a composition and a sample size of 32 students was obtained from the population. Purposive sampling was used to select 16 boys and 16 girls who have had good mastery of English language in the classroom before Covid-19 pandemic. Most of the students selected come from a cosmopolitan region and were bilingual or multilingual; they speak English, Kiswahili and other language (s). 


\subsection{Data collection procedure}

A guided composition was used to collect data for this research. Students were given an informal letter to inform their parents of a scenario that took place on opening day after the nine and a half months of closure due to Covid-19 pandemic. Students wrote the composition within forty minutes under the supervision of the researcher.

\subsection{Data analysis procedure}

After 40 minutes, the researcher collected students' compositions to identify aspects of grammar that indicated attrition far below the expected norm of the chosen students. The grammatical errors were categorised as tense related, determiners as well as spelling mistakes. Frequency counts and their respective percentages were obtained and used to answer the research question.

Researchers categorised the errors in six options that were corresponding to codes: No errors $=$ Excellent $(E)$, Very few errors $=$ Very Good $(\mathrm{VG})$, Few errors $=$ Good $(\mathrm{G})$, Moderate errors $=$ Fair $(\mathrm{F})$, High number of errors $=$ Poor $(\mathrm{P})$ Very high number of errors $=$ Very Poor $(\mathrm{VP})$.

* Ungrammatical word or sentence

\section{VIII. $3.0 \quad$ FINDINGS}

The objective of the study was to find out which aspects of grammar suffered attrition amid Covid-19 pandemic due to the long closure of schools. From the data analysis students had more than the norm errors and mistakes in tense marking, determiner use and exhibited increased spelling mistakes.

\subsection{Grammatical errors \\ 3.1.1 Tense marking errors}

Table 1.

\begin{tabular}{|c|c|c|c|}
\hline Errors & Rating & $\begin{array}{l}\text { Students } \\
\text { Frequency }\end{array}$ & $\%$ \\
\hline No errors & Excellent $[E]$ & 0 & 0.0 \\
\hline Very few errors & $\begin{array}{l}\text { Very } \\
\text { [VG] }\end{array}$ & 2 & 6.25 \\
\hline Few errors & Good [G] & 4 & 12.5 \\
\hline Moderate errors & Fair $[\mathrm{F}]$ & 6 & 18.75 \\
\hline $\begin{array}{l}\text { High number of } \\
\text { errors }\end{array}$ & Poor $[\mathrm{P}]$ & 9 & 28.125 \\
\hline $\begin{array}{l}\text { Very high number } \\
\text { of errors }\end{array}$ & $\begin{array}{l}\text { Very } \\
\text { [VP] }\end{array}$ & 11 & 34.375 \\
\hline Totals & & 32 & 100 \\
\hline
\end{tabular}

Table 1 shows that students regressed in their English language skills with no $0(0 \%)$ student writing a composition without errors, $2(6.25 \%)$ of the students exhibited very few errors producing very good compositions while $4(12.5 \%)$ had few errors indicating good compositions whereas $6(18.75 \%)$ had moderate errors with fair compositions. 9 (28.125\%) of the students had very high number of errors showing poor compositions whilst a majority of the students $11(34.375 \%)$ exhibited very high number of errors indicating very poor compositions.
Examples of tense marking ungrammatical sentences include * within a minutes, *was already been stop, *they found two student, *five hundred shilling, *had ask (had asked), *they had call you (they had called you), *you have try (you have tried) *there is some people (there are some people) *parents may be call upon (parents may be called upon), *...no one have experience the signs...(...no one has experienced the signs..), *becaming (be coming).

\subsection{Determiner errors}

Table 2

\begin{tabular}{|c|c|c|c|}
\hline Errors & Rating & $\begin{array}{l}\text { Students } \\
\text { Frequency }\end{array}$ & $\%$ \\
\hline No errors & Excellent [E] & 3 & 9.375 \\
\hline Very few errors & $\begin{array}{l}\text { Very Good } \\
\text { [VG] }\end{array}$ & 1 & 3.125 \\
\hline Few errors & Good $[\mathrm{G}]$ & 9 & 28.125 \\
\hline Moderate errors & Fair $[\mathrm{F}]$ & 10 & 31.25 \\
\hline $\begin{array}{l}\text { High number of } \\
\text { errors }\end{array}$ & Poor $[\mathrm{P}]$ & 7 & 21.875 \\
\hline $\begin{array}{l}\text { Very high number } \\
\text { of errors }\end{array}$ & $\begin{array}{l}\text { Very } \\
{[\text { VP] }}\end{array}$ & 2 & 6.25 \\
\hline Totals & & 32 & 100 \\
\hline
\end{tabular}

Results in table 2 show that $3(9.375 \%)$ of the students had excellent compositions with no determiner errors while 1 $(3.125 \%)$ had very few errors writing very good compositions and $9(28.125 \%)$ producing good compositions which had few errors. Majority of the students 10 (31.25\%) had moderate errors with their compositions rated fair followed by 7 (21.875\%) of the students who exhibited high number of errors and their compositions rated poor whereas only $2(6.25 \%)$ had very high number of errors indicating very poor compositions.

Students showed increased errors in the determiners this/these for example *these letter (this letter), there/their, the/they, omissions and inclusions of 'the' as well as interchanging 'the' with 'a' thereby producing ungrammatical sentences.

\subsection{Spelling mistakes}

Table 3.

\begin{tabular}{|llll|}
\hline Errors & Rating & $\begin{array}{l}\text { Students } \\
\text { Frequency }\end{array}$ & \% \\
\hline $\begin{array}{l}\text { No mistakes } \\
\begin{array}{l}\text { Very } \\
\text { mistakes }\end{array}\end{array}$ & Excellent [E] & 0 & 0.0 \\
$\begin{array}{l}\text { Few mistakes } \\
\begin{array}{l}\text { Moderate } \\
\text { mistakes }\end{array}\end{array}$ & $\begin{array}{l}\text { Very Good } \\
\text { [VG] }\end{array}$ & 1 & 3.125 \\
$\begin{array}{l}\text { High number } \\
\text { mistakes }\end{array}$ & Fair [F] & 2 & 6.25 \\
$\begin{array}{l}\text { Very high number } \\
\text { of mistakes }\end{array}$ & Poor [P] & 4 & 12.5 \\
\hline Totals & Very Poor [VP] & 14 & 34.375 \\
\hline
\end{tabular}


Table 3 shows the frequency of spelling mistakes that students exhibited in their compositions. No student $0(0.0 \%)$ had no spelling mistakes and only $1(3.125 \%)$ had very few mistakes hence writing a very good composition. 2 (6.25\%) had few spelling mistakes with good compositions while $4(12.5 \%)$ had moderate mistakes with fair compositions. $11(34.375 \%)$ wrote compositions with a high number of mistakes which were rated poor. A majority of the students had very high number of mistakes $14(43.75 \%)$ with the compositions rated very poor in terms of spelling mistakes.

Examples of spelling mistakes produced include: *explotion (explosion), *writting (writing), *erged (urged),

*had (heard), *hard (heard), *dometry (dormitory), *felling well (feeling well), *end mounth (end month)

*quie (queue), *strait (straight), *docter (doctor), *realy (really), *bank (bang).

\section{CONCLUSION}

Data from the study found out that students showed language attrition in inflectional morphological in tense marking where increased errors sufficed, proper use of determiners in sentences showed reduced proficiency and students produced a lot of spelling mistakes in their written compositions. The findings show that different aspects of grammar will suffer attrition due to reduced or diminished language use.

\section{REFERENCES}

[1] Akabigym J.U., Mbali, B.M. (2013). Second Language Acquisition, Attrition of Indigenous Languages in Nigeria: Cultural Implication. IOSR. Vol. 13, Issue 4. Available online at: www.iosr.journals.org

[2] Akmajian, A., Farmer, A.K., Bickmore, A., Demers, R.A., and Harnish, R.M (2019). Linguistics: An Introduction to Language and Communication. (7th Edition). New York, NY: The MIT Press.

[3] Ammerlaan, T. (1996). "You get a bit wobbly..." Exploring bilingual retrieval processes in the context of first language attrition. Available online at: www.repository.ubn.ru.nl

[4] Bahrick, H.P. (1984). Fifty Years of Second Language Attrition: Implications for Programmatic Research. The Modern Language Journal. Available online at: www.jstor.org

[5] Bardovi-Harlig, K., Stringer, D. (2010). Variables in Second Language Attrition. Advancing the State of the Art. Studies in Second Language Acquisition, 32, 1-45. Available online at: www.academia.edu

[6] Cleroux, D. (2013). Acquiring and Maintaining Second Language Skills: An Examination of Canadian Federal Public Service Programs. M.ED Dissertation. Available online at: www.qspace.library.queensu.ca

[7] Davies, A., Elder, C. (2004). The Handbook of Applied Linguistics. Blackwell Publishing Ltd.Available online at: www.academia.edu

[8] Feng, H. (2016). Overview on Language Attrition Theory. International Conference on Education, Management, Computer and Society. www.atlantis-press.com

[9] Gardner, R.C., Lalonde, R. N., MacPherson, J. (1985). Social Factors In Second Language Attrition. Available online at: www.onlinelibrary.wiley.com

[10] Gardner, R.C., Lalonde, R.N., Moorcroft, R., Evers, F.T. (1987). Second Language Attrition: The Role of Motivation and Use. Journal of Language and Social Psychology. Vol. 6. No.1 Available online at: www.researchgate.net

[11] Hayashi, G. (2011). Language Attrition of Japanese Returnee Students: Accents Asia. www.accentsasia.org
[12] Hulsen, M. (2000). Language Loss and Language Processing. Three Generations of Dutch Migrants in New Zealand. Available online at: www.repository.ubn.ru.nl

[13] Kaviti, L. (2018). The new curriculum of Education in Kenya: A Linguistic and Education

[14] Paradigm Shift. International Journal of Novel Research in Education and Learning. Vol. 5, Issue 1, pp: (15-27). Available online at: www.noveltyjournals.com

[15] Kopke, B, Schmid M.S. (2004). Language Attrition. https://repositoty.essex.ac.uk

[16] Kopke, B., Schmid. M. (2013). Language Attrition: The next phrase. Available online at: https://hal.archives-ouvertes.fr

[17] Kupske, F.F. (2020). The Impact of Language Attrition on Language Teaching: The Dynamics of Language Knowledge Retention and Maintenance in Multilingualism. www.scielo.br

[18] Meara, P. (2004). Modelling vocabulary loss. Applied Linguistics, 25(2), 137-155. www.googlescholar.com

[19] Maithya, P.M., Mukolwe, N.A., Waka, M. (2019). Research Methodology. Concepts, Procedures and Practices. Franciscan Kolbe Press, Limuru

[20] Marefat, H., Rouhshad, A. (2007). Second language attrition: Are different nouns equally likely to be lost? Available online at: www.citeseerx.ist.psu.edu

[21] Myers-Scotton, C. 2006. Multiple voices. An introduction to bilingualism. Malden, MA:Blackwell Publishers.

[22] O'Grady, W., Schafer, A. J., Perla, J., Lee, O., Wieting, J. (2009). A Psycholinguistic Tool for the Assessment of Language Loss: The Hala Project. Language Documentation \& Conservation. Vol. 3, No. 1. Pp. 100112. Available online at: www.scholarspace.manoa.hawaii.edu

[23] Olshtain, E. (1989). Is Second Language Attrition The Reversal of Second Language Acquisition? Studies in Second Language Acquisition. Vol. 11, No. 2., pp. 151-165. Available online at: www.jstor.org

[24] Olshtain, E. (1986). The attrition of English as a second language: a case of Hebrew speaking children. Available online at: www.researchgate.net

[25] Olshtain, E. 1986. "The attrition of English as a second language with speakers of Hebrew. In Language attrition in progress, B. Weltens, K. de Bot and T. van Els (eds), 187-204. Dordrecht: Foris.

[26] Ouane, A., Christine, G. (2011). Optimising Learning, Education and Publishing in Africa: The Language Factor. A review and analysis of Theory and Practice in Mother-Tongue and Bilingual Education in Sub-Saharan Africa. Unesco Institute for Lifelong Learning. Available online at: www.academia.edu

[27] Paradis, M. (2004). A neurolinguistic theory of bilingualism. John Benjamins Publishing. www.google.scholar.com

[28] Park, E.S. (2018). Language Attrition: The Intellectual and Social Context of Language Attrition. Available online at: www.academia.edu

[29] Piper, B., Zuilkowski, S.S., Ong'ele, S. (2016). Implementing Mother Tongue Instruction in the Real World: Results from a Medium-Scale Randomized Controlled Trial in Kenya. Comparative Education Review. Vol. 60. No. 4. Available online at: www.journals.uchicago.edu

[30] Pyrzanowska, M.S. (2016). Language Attrition - Implications for Second/Foreign Language Acquisition. Available online at: www.alp.uw.edu.pl

[31] Schmid, M.S., Keizer, M. (2005). Building Language Attrition Research. Available online at: www.researchgate.net

[32] Schmid, M.S. (2011) Language Attrition. Available online at: www.researchgate.net

[33] Schmid, M. S., Mehotcheva, T. (2012). Foreign Language Attrition. Dutch Journal of Applied Linguistics. Vol.1. Issue 1. www.jbe-platform.com

[34] Schmid, M. S. (2002). First language attrition, use and maintenance: The case of German Jews in Anglophone countries. Amsterdam: John Benjamins

[35] Tang, A. (2011). From Diagnosis To Remedial Plan: A Psycholinguistic Assessment of Language Shift, L1 Proficiency, and Language Planning in Truku Seediq. PhD Thesis. www.ling.hawaii.edu

[36] Wabwoba, C.N., Okoth, U.A., Mugambi, M. (2017). Influence of Collaborative Methods on Pupil's performance in English Language in Kenya Certificate of Primary Education in Non Formal Schools in Korogocho, Nairobi, Kenya. Journal of Education and Practice. Vol. 8. No. 28. Available online at: www.iiste.org 
[37] Wei, J. (2014). Selectivity of Second Language Attrition: Theory and Practice in Language Studies. Vol. 4., No., 8. Available online at: www.academypublication.com

\section{AUTHORS}

First Author - Sara Zinyuk, PhD candidate, University of Nairobi.sarazinyuk@gmail.com

Second Author - Josiah Mwachi Waiti, PhD candidate, University of Nairobi. josiahmwachi@gmail.com 